\title{
Carbonation of Municipal Solid Waste Incineration Fly Ash and the Impact on Metal Mobility
}

\author{
Holger Ecke ${ }^{1}$; Nourreddine Menad ${ }^{2}$; and Anders Lagerkvist ${ }^{3}$
}

\begin{abstract}
Fly ash from municipal solid waste incineration (MSWI) is considered as hazardous waste that calls for a robust, reliable, and reasonable treatment technique. This investigation aims to assess the impact of $\mathrm{CO}_{2}$ partial pressure, water addition, time, and temperature on the stabilization of MSWI fly ash with particular emphasis on $\mathrm{Pb}, \mathrm{Zn}, \mathrm{Cd}$, and $\mathrm{Cr}$. Carbonation and element mobility were studied by applying thermal analysis and leaching assays on fly ash samples treated according to a $2^{4}$ factorial design. The relationship between the factors and the response variables was evaluated using partial least squares modeling. Chemical equilibrium calculations were performed so as to complement the experimental findings. Decalcification of carbonated fly ash in a typical Swedish landfill was estimated at 0.13 $\mathrm{mm} \cdot \mathrm{yr}^{-1}$ Treatment through carbonation reduced the availability of $\mathrm{Pb}$ and $\mathrm{Zn}$ about 100 times and also the carbonate alkalinity of $7.4 \mathrm{eq} \cdot(\mathrm{kg} \cdot \mathrm{FS})^{-1}$ (FS represents the fixed solids) was remedied successfully. However, shortcomings that need to be resolved are the remobilization of $\mathrm{Cr}$ with time and the mobilization of $\mathrm{Cd}$.
\end{abstract}

DOI: 10.1061/(ASCE)0733-9372(2003)129:5(435)

CE Database subject headings: Fly ash; Stabilization; Carbonation; Metals; Solid wastes; Leaching; Thermal analysis.

\section{Introduction}

Municipal solid waste incineration (MSWI), including air pollution control (APC), is a way to separate inorganic contaminants from bulk municipal solid waste and to collect them in a solid waste stream. The APC stream corresponds to only $\sim 2.5 \%$ by weight of the incinerator feed, but contains $\sim 90 \%$ of $\mathrm{Hg}, \sim 86 \%$ of $\mathrm{Cd}, \sim 40 \%$ of $\mathrm{Zn}$, and $31 \%$ of $\mathrm{Pb}$ (Chandler et al. 1997). Once these pollutants are concentrated, they should be deposited with care.

Owing to the content of hazardous components, different countries have tightened up their legislation regarding the handling of APC residues. The European Commission (EC), for example, classifies APC residues from MSWI as hazardous waste [European Union (EU) 1991]. As such it has to be disposed of at a landfill that fulfills strict technical and monitoring requirements (EU 1999). In addition, the EC Landfill Directive (EU 1999) requires that all waste undergo pretreatment to reduce its hazardous nature. Japan's Waste Disposal and Public Cleansing Law [Ministry of Health and Welfare (MHW) 1991] stipulates that for all MSW incinerators with a capacity equal to or greater than $5 \mathrm{t} \cdot \mathrm{day}^{-1}$, APC residues must not be disposed of unless treated.

\footnotetext{
${ }^{1}$ Doctor of Science, Division of Waste Science and Technology, Lulea Univ. of Technology, SE-971 87 Luleå, Sweden. E-mail: Holger.Ecke@sb.luth.se

${ }^{2}$ Doctor of Science, Division of Process Metallurgy, Luleå Univ. of Technology, SE-971 87 Luleå, Sweden. E-mail: nome@km.luth.se

${ }^{3}$ Professor and Head, Division of Waste Science and Technology, Luleå Univ. of Technology, SE-971 87 Luleå, Sweden. E-mail: Anders.Lagerkvist@sb.luth.se

Note. Associate Editor: Morton A. Barlaz. Discussion open until October 1, 2003. Separate discussions must be submitted for individual papers. To extend the closing date by one month, a written request must be filed with the ASCE Managing Editor. The manuscript for this paper was submitted for review and possible publication on January 15, 2002: approved on April 16, 2002. This paper is part of the Journal of Environmental Engineering, Vol. 129, No. 5, May 1, 2003. CASCE, ISSN $0733-$ 9372/2003/5-435-440/\$18.00.
}

In spite of the need for APC residue treatment, no technique has gained wide acceptance. Thermal treatment in electric, burner, or blast furnaces strains resources, amounting to operation costs of up to $\$ 500$ per ton (Ecke et al. 2000). Cementitious stabilization and solidification almost triple the final waste mass while microencapsulation, which uses organic additives such as bitumen, paraffin, and polyethylene, requires expensive equipment and skilled labor (Chandler et al. 1997). Chemical stabilization with inorganic additives is still under development and assessment. Different additives were tested (Chandler et al. 1997), such as phosphates (Eighmy et al. 1997), sulfides, lime (Reardon and Della Valle 1997), clays, and carbonates. In the long term, the approach of stabilizing rather than solidifying APC residues might be superior, provided that the treated waste is placed in an environment not counteractive to the fixation of pollutants.

This work presents a new attempt, adopted from geochemical processes, to stabilize APC residues. Based on a treatmentoriented characterization of typical MSWI fly ash, it is suggested assessing carbonation as a stabilization method (Ecke et al. 2002). Using the same waste as for characterization, the objective of the present investigation was to study factors that possibly control carbonation and its impact on metal mobility. With reference to promising carbonation experiments on coal fly ash and spent shale (Reddy et al. 1991, 1994; Tawfic et al. 1995), the working hypothesis was that the availability of crucial metals (Ecke et al. 2002) such as $\mathrm{Pb}$ and $\mathrm{Zn}$, and possibly $\mathrm{Cr}$ and $\mathrm{Cd}$, can be lowered to meet the strictest EC standards for landfill leachate (Hjelmar et al. 1994).

\section{Material and Methods}

The fly ash used in this investigation was sampled from the MSW incinerator Ålidshemverket in Umeå, Sweden. The flue gas is treated in several steps. Ammonia is injected into the combustion chamber to reduce nitrous fumes. Sodium sulfide is added to remove $\mathrm{Hg}$ and calcium hydroxide is added to neutralize acid com- 


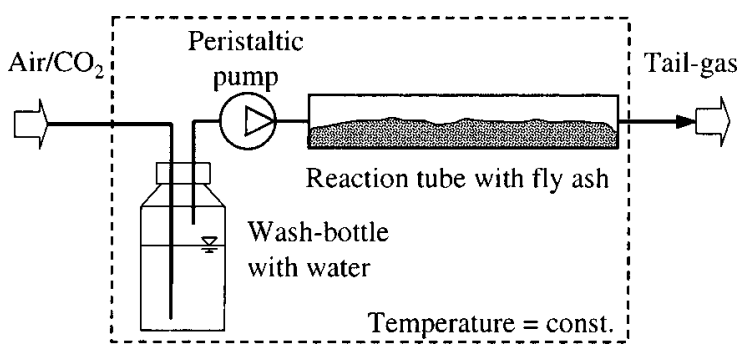

Fig. 1. Experimental setup used for the carbonation of fly ash

ponents. Bag fabric filters are used to remove particulate matter. This material is the research object called fly ash. During one week of regular plant operation, about $5 \mathrm{~kg}$ of fly ash were sampled three times per day and once per shift. The material was mixed and quartered to obtain subsamples.

\section{Carbonation}

In the laboratory, $10 \mathrm{~g}$ of fly ash were carbonated in 16 experimental runs. They were varied according to a two-level full factorial design (Box et al. 1978), where the impacts of four factors were studied, viz., addition of water, partial pressure of $\mathrm{CO}_{2}$, temperature, and time. The fly ash was used as received or mixed with water. The material was placed in glass reaction tubes (Fig. 1). By applying a peristaltic pump, the daily total gas flow through the tubes was set at $2.2 \mathrm{~L}$. The gas became saturated with moisture by passing through a washbottle. The water in the washbottle was in chemical equilibrium with the reaction gas (open system), either air or air mixed with $\mathrm{CO}_{2}$, before running the experiments. During carbonation, the temperature was kept constant using laboratory ambient conditions $\left(20^{\circ} \mathrm{C}\right)$ or an oven $\left(60^{\circ} \mathrm{C}\right)$. The experiments were terminated after either 4 or 40 days. The factor levels are summarized in Table 1.

Carbonated samples were crushed and homogenized with a pestle before analysis.

Table 1. $2^{4}$ Full Factorial Design for the Carbonation of Fly Ash

\begin{tabular}{lcccc}
\hline $\begin{array}{l}\text { Experiment } \\
\text { number }\end{array}$ & $\begin{array}{c}\text { Time } \\
(\text { days })\end{array}$ & $\begin{array}{c}\text { Temperature } \\
\left({ }^{\circ} \mathrm{C}\right)\end{array}$ & $\begin{array}{c}\mathrm{CO}_{2} \\
(\% \text { by volume })\end{array}$ & $\begin{array}{c}\mathrm{H}_{2} \mathrm{O} \text { addition } \\
(\mathrm{kg} / \mathrm{kg})\end{array}$ \\
\hline 1 & 4 & 20 & 0.03 & 0.0 \\
2 & 40 & 20 & 0.03 & 0.0 \\
3 & 4 & 60 & 0.03 & 0.0 \\
4 & 40 & 60 & 0.03 & 0.0 \\
5 & 4 & 20 & 50 & 0.0 \\
6 & 40 & 20 & 50 & 0.0 \\
7 & 4 & 60 & 50 & 0.0 \\
8 & 40 & 60 & 50 & 0.0 \\
9 & 4 & 20 & 0.03 & 0.5 \\
10 & 40 & 20 & 0.03 & 0.5 \\
11 & 4 & 60 & 0.03 & 0.5 \\
12 & 40 & 60 & 0.03 & 0.5 \\
13 & 4 & 20 & 50 & 0.5 \\
14 & 40 & 20 & 50 & 0.5 \\
15 & 4 & 60 & 50 & 0.5 \\
16 & 40 & 60 & 50 & 0.5 \\
\hline
\end{tabular}

\section{Analytical Methods}

Thermal analysis (Netzsch STA 409C) was performed in air by applying thermogravimetry (TG) and differential thermal analysis (DTA) in a temperature range of $20-1200^{\circ} \mathrm{C}$ at a heating rate of $10 \mathrm{~K} \cdot \mathrm{min}^{-1}$. The crucible material was aluminum oxide ceramic. Differential thermal analysis and the first derivative of the TG curves were used to determine the temperature range for the decomposition of different phases.

$\mathrm{pH}_{\text {stat }}$ titrations (Cremer and Obermann 1992) were performed under $\mathrm{Ar}$ atmosphere using an initial liquid-to-solid (L/S) ratio of $401 \cdot(\mathrm{kg} \text { fixed solids })^{-1}$. One molar nitric acid, used as titrant, was added by a computer-controlled automatic titrator (Radiometer $\mathrm{ABU}$ 900). The titration time was set at $12 \mathrm{~h}$. The titration levels were $\mathrm{pH} 8.3$ and 4.5 . Total titrant addition was recorded. All suspensions were filtered $(0.45 \mu \mathrm{m})$.

Zero-headspace water leaching assays were performed on a laboratory roller mixer. The L/S ratio, leaching time, and sample treatment were identical to the $\mathrm{pH}_{\text {stat }}$ titrations. The final $\mathrm{pH}$ of the leachate (denoted here as $\mathrm{pH} \_0$ ) was determined.

The elemental compositions of the leachates from both $\mathrm{pH}_{\text {stat }}$ titrations and zero-headspace leachings were analyzed using inductively coupled plasma mass spectrometry at an accredited laboratory (SGAB Analytica, Luleå, Sweden).

Chemical equilibrium calculations were performed using the computer program PHREEQC-2 (Parkhurst and Appelo 1999) and applying the LLNL thermodynamic database developed by the Lawrence Livermore National Laboratory, Livermore, Calif.

\section{Statistics}

Partial least squares (PLS) modeling (Cooley and Lohnes 1971; Wold 1989) was used to find the relationships between the response variables and the factors. Cross validation was applied to identify the appropriate number of principal components (Wold et al. 1987; Wold 1989).

\section{Results and Discussion}

A former characterization (Ecke et al. 2002) of the same MSWI fly ash showed that the material was both representative and homogeneous. The total contents of abundant elements were within the minimum-maximum ranges of dry/semidry APC residues as compiled by the International Ash Working Group (IAWG) (Chandler et al. 1997). For elements at lower concentrations, the deviations from the IAWG data were less than one order of magnitude. The standard deviation for the sum of all elements was less than $1.5 \%$. 2.6 $1.5 \%$ per weight of the dry solids was not identified, which can be due to elements such as $\mathrm{N}$ and Se that were not analyzed.

Thermal analysis of the 16 treated samples showed that the fly ash consisted of three major volatile phases, viz., pore water, hydrated water, and carbonates (Fig. 2). Evaporation of pore water is an endothermic process and was observed up to $\sim 230^{\circ} \mathrm{C}$. While hydrated water was liberated within a broad temperature range between $\sim 230$ and $\sim 640^{\circ} \mathrm{C}$, the combustion of organics occurred at $\sim 470^{\circ} \mathrm{C}$. The latter was characterized by small positive peaks in the DTA curves. However, the mass loss due to organics was estimated at less than $1.5 \%$ by weight compared with a total mass loss of up to about one-third at $550^{\circ} \mathrm{C}$. This outcome shows that the loss on ignition analyzed according to standard methods, e.g., CEN (2000), is inappropriate to determine the content of organics in fly ashes. Fly ash dried at $105^{\circ} \mathrm{C}$ still 


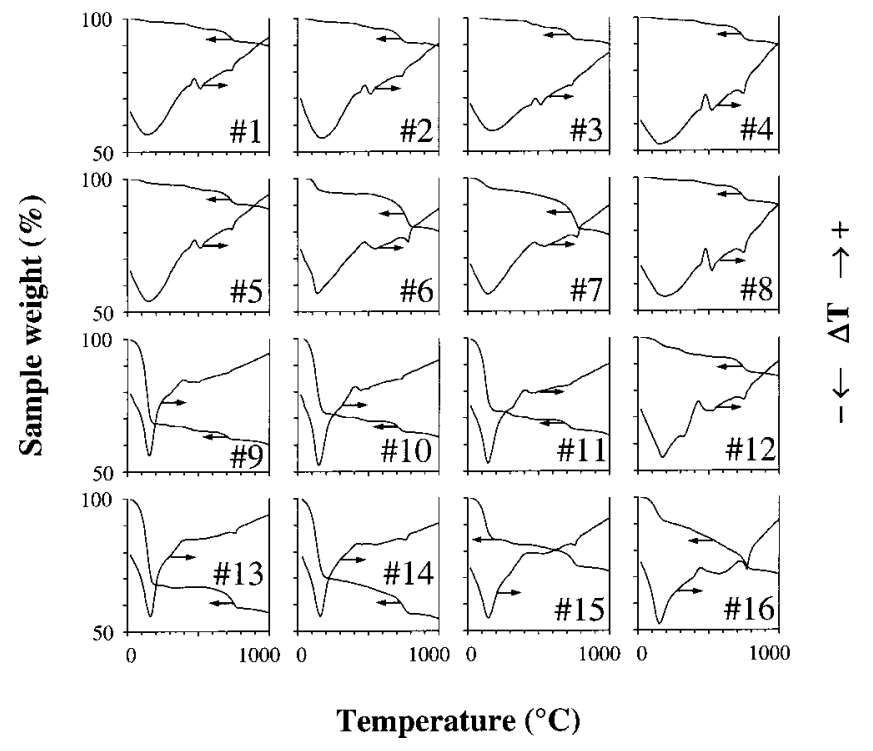

Fig. 2. Thermograms for 16 carbonated fly ash samples (Table 1). Each diagram illustrates both the thermogravimetric analysis and the differential thermal analysis. Positive and negative $\Delta T$ peaks qualitatively indicate exothermic and endothermic reactions, respectively.

contained significant amounts of mechanically and chemically bound water, hence dominating the loss on ignition (Fig. 2).

Carbonates were decomposed in a temperature range of $\sim 640-840^{\circ} \mathrm{C}$. To avoid underestimating both the formation of such new phases and the leachability of metals, the concentrations of the components were related to the fixed solids (FSs). In the following, the term FS is defined as the mass remaining after the evaporation of water, the oxidation of organics, and the decomposition of carbonates.

The data matrix consisted of 16 observations on four factors and responses from TG as well as leachate analyses from three different leachings including multiple element analyses. Due to the complexity of the data matrix itself and possible variable interactions, the data evaluation was performed by means of PLS modeling. Input data were expressed on the basis of FSs. Variables not at all affected by the factors were excluded from the modeling. $\log _{10}$ transformations were performed on skewed variable data sets.

The PLS modeling resulted in two principal components comprising 43 and $13 \%$ of the data variation. The loading plot (Fig. 3) illustrates the impact of the factors on the response variables. For the following discussion and its conclusions, it is important to keep in mind that the received model covers $56 \%$ of the data variation, i.e., there still remains unresolved variability, due to either noise or the impact of factors that were not considered.

The carbonate content depended greatly on the concentration of $\mathrm{CO}_{2}$ in the gas phase, but also on water addition and time. The content of pore water was dominated by the amount of added water, whereas time and temperature had a somewhat negative effect. Both $\mathrm{CO}_{2}$, water additions, and time increased the content of hydrates. The effects of the factors $\mathrm{CO}_{2}$ and time are quantified in Fig. 4.

The factors $\mathrm{CO}_{2}$ and time both had a negative effect on the $\mathrm{pH}$ of the zero-headspace leachates $\left(\mathrm{pH}_{-} 0\right)$ and the acid addition at $\mathrm{pH}_{\text {stat }} 8.3$ (carbonate alkalinity Alk_C) (Figs. 3 and 5). The maximum difference observed in $\mathrm{pH}_{0}$ was almost 5 units from 13.1 (observation No. 4) to 8.5 (observation No. 16), illustrating that
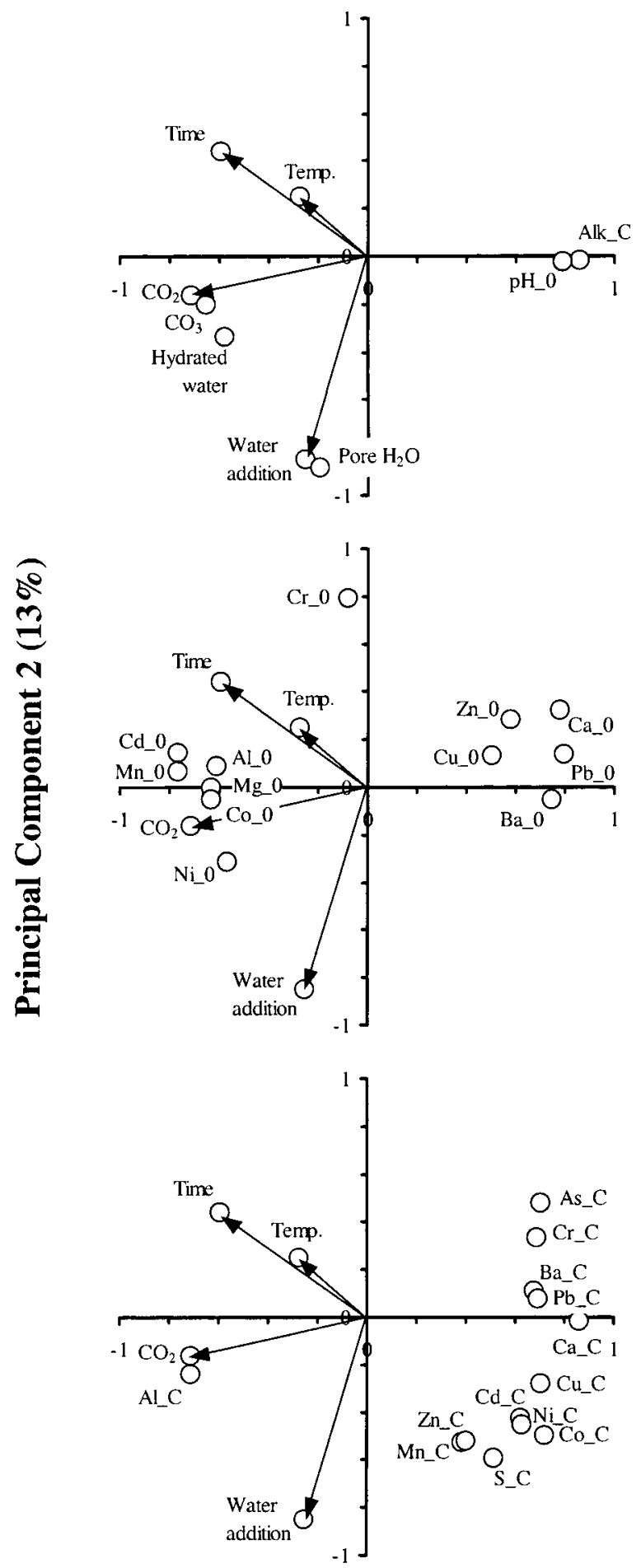

Principal Component $1(43 \%)$

Fig. 3. Partial least squares loadings illustrated in three plots. Factors are set off with arrows. Notations for response variables: _0 means zero-headspace leaching, _C means $\mathrm{pH}_{\text {stat }}$ leaching at $\mathrm{pH} 8.3$.

carbonation at its extreme (all factors high) resulted in a carbonate system dominated by bicarbonates.

Carbonation also affected the leaching behavior of several metals as investigated by zero-headspace assays (notation_0) and $\mathrm{pH}_{\text {stat }} 8.3$ assays (notation_C) (Fig. 3). Without any $\mathrm{pH}$ adjustment (_0), two major element groups were identified. For the first, 


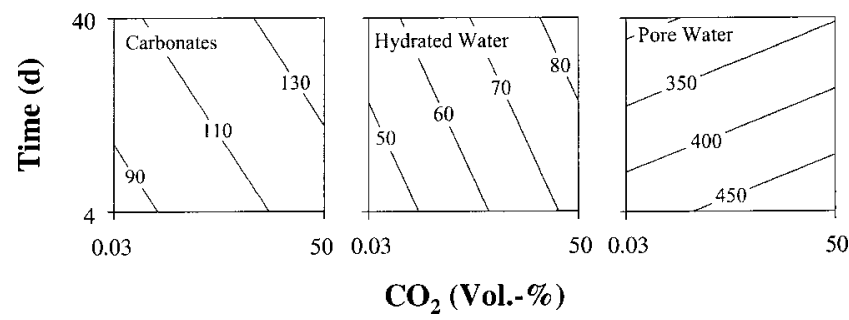

Fig. 4. Evolution of the content of carbonate, hydrated water, and pore water in $\mathrm{g} \cdot(\mathrm{kg} \cdot \mathrm{FS})^{-1}$ as function of $\mathrm{CO}_{2}$ concentration and time using the partial least squares model. Constant factor levels: water addition $0.50 \mathrm{~kg} \cdot \mathrm{kg}^{-1}$ and temperature $20^{\circ} \mathrm{C}$.

metal availability decreased with an increased concentration of $\mathrm{CO}_{2}$ and time. For the second group, the same factors had the opposite effect, i.e., they increased the mobility. The first group depicts three typical carbonate formers, viz., $\mathrm{Ca}, \mathrm{Ba}$, and $\mathrm{Pb}$ forming calcite, witherite, and cerussite. In addition, the two remaining elements of that group, $\mathrm{Zn}$ and $\mathrm{Cu}$, can be bound as carbonaceous phases; $\mathrm{Zn}$ preferably as smithonite and $\mathrm{Cu}$ as malachite. The grouping demonstrates that carbonation demobilized environmentally relevant metals such as $\mathrm{Pb}$ and $\mathrm{Zn}$ while mobilizing $\mathrm{Cd}, \mathrm{Al}$, $\mathrm{Ni}$, and $\mathrm{Mn}$. $\mathrm{Cr}$ was an exception because its availability was almost unaffected by $\mathrm{CO}_{2}$; however, time appeared to have a positive impact while water addition had a negative influence (Figs. 3 and 5).

These findings complement former investigations (Ecke et al. 2002). With respect to the strictest EC limit values for landfill leachate, Ecke and co-workers identified in the cited study $\mathrm{Pb}, \mathrm{Zn}$, $\mathrm{Cr}$, and $\mathrm{Cd}$ as the potential major pollutants in fly ash from MSWI. Based on chemical equilibrium calculations, it was postulated that carbonation leads to a reduced mobility of $\mathrm{Pb}$ and $\mathrm{Zn}$ due to the predominance of $\mathrm{PbCO}_{3}(6<\mathrm{pH}<9)$ and $\mathrm{Zn}(\mathrm{OH})_{2}(9$ $<\mathrm{pH}<11$ ), respectively, while the availability of $\mathrm{Cr}$ is a function of both carbonation and electron activity. A change in $\mathrm{Cd}$ mobility could not be deduced.

The two investigations are in good agreement with regards to $\mathrm{Pb}$ and $\mathrm{Zn}$. As an effect of carbonation, the leachability of $\mathrm{Pb}$ and $\mathrm{Zn}$ decreased by two orders of magnitude and yielded for both $\sim 1$



Fig. 5. Leachate $\mathrm{pH}$ and leachability $\left[\mathrm{mg} \cdot(\mathrm{kg} \cdot \mathrm{FS})^{-1}\right]$ of $\mathrm{Al}, \mathrm{Cd}, \mathrm{Cr}$, $\mathrm{Pb}$, and $\mathrm{Zn}$ determined by zero-headspace leachings. Responses illustrated as function of $\mathrm{CO}_{2}$ concentration and time using the partial least squares model. Constant factor levels: water addition 0.50 $\mathrm{kg} \cdot \mathrm{kg}^{-1}$ and temperature $20^{\circ} \mathrm{C}$. $\mathrm{mg} \cdot(\mathrm{kg} \cdot \mathrm{FS})^{-1}$ at a minimum (Fig. 5). Carbonation increased the mobility of $\mathrm{Cd}$ (Fig. 5) possibly due to the transition from $\mathrm{Cd}(\mathrm{OH})_{2}$ to $\mathrm{CdCl}_{2}$ (Ecke et al. 2002). From an environmental point of view, this observation is critical and calls for extra attention in future investigations. According to Ecke et al. (2002), the mobility pattern of $\mathrm{Cr}$ can be attributed to pe rather than other factors such as $\mathrm{CO}_{2}$ or $\mathrm{pH}$. At pe $>4$, highly mobile hexavalent $\mathrm{Cr}(\mathrm{VI})$ dominates the fly ash leachate system. As a function of time, the fly ash samples might have been treated toward more oxidizing conditions due to the impact of atmospheric $\mathrm{O}_{2}$, i.e., the mobilization of $\mathrm{Cr}$ was favored. On the other hand, mixing fly ash with water might have facilitated the chemical reaction with other elements and, thus, the reduction of $\mathrm{Cr}(\mathrm{VI})$ to species in the trivalent oxidation state, which is characterized by a much lower mobility, as in $\mathrm{Cr}(\mathrm{OH})_{3}$.

Ecke et al. (2002) found that for fresh fly ash leached at $\mathrm{pH}_{\text {stat }}$ 8.3 , the leachability of $\mathrm{Pb}$ decreased by three orders of magnitude compared with zero-headspace leachings ( $\mathrm{pH}_{-}$0). Other metals are barely affected and remain at low levels, e.g., $\mathrm{Al}, \mathrm{Cd}, \mathrm{Cu}, \mathrm{Ni}$, and $\mathrm{Zn}$. Except for $\mathrm{Al}$, the carbonation led to an even more reduced availability at $\mathrm{pH}_{\text {stat }} 8.3$ (_C in Fig. 3), especially for all crucial metals, i.e., $\mathrm{Pb}, \mathrm{Zn}, \mathrm{Cd}$, and $\mathrm{Cr}$. Among the latter, the addition of water appeared to have a positive effect on the availability of $\mathrm{Zn}$ and $\mathrm{Cd}$; however, the increase in mobility of $\mathrm{Zn}$ and $\mathrm{Cd}$ diminished with time.

Some observations were also likely based on or had interference from secondary effects. Significant impacts might be due to the formation of calcium silicate hydrates $(\mathrm{C}-\mathrm{S}-\mathrm{H})$ or calcium aluminosilicate hydrates (C-A-S-H) (Ecke et al. 2002). Through bonding and adsorption, the crystalline matrix retains the metals. However, carbonation can cause the decomposition of silicates as observed during the weathering of natural silicates (Appelo and Postma 1999), which could explain the anomalous behavior of $\mathrm{Al}$ (Fig. 3). An effect that enhances the sequestering of a variety of cations $(\mathrm{Pb}, \mathrm{Cd}, \mathrm{Cu}, \mathrm{Zn}$, etc.) is probably the adsorption onto $\mathrm{CaCO}_{3}$ leading to coprecipitation (Morse and Bender 1990; Stumm 1992; Gutjahr et al. 1996; Rimstidt et al. 1998; Schwartz and Ploethner 2000). This is a possible explanation for the reduced availability of $\mathrm{Cu}$. However, the mobility pattern of $\mathrm{Cd}$ must be attributed to other processes because carbonation mobilized Cd when leached at pH_0.

With respect to the two principal components (Fig. 3), temperature had the lowest factor importance. However, temperature correlated with time, indicating that the higher the temperature, the more carbonation was favored.

All variables belonging to the $\mathrm{pH}_{\text {stat }} 4.5$ leachings were omitted from the PLS modeling because data variations were dominated by noise and could not be related to the factors. Thus, carbonation did not considerably change the leaching characteristics of fly ash at low $\mathrm{pH}$. This implies that metal mobility at $\mathrm{pH}$ 4.5 was still high (Ecke et al. 2002), thereby emphasizing the need for measures to counteract acidification in MSWI fly ash landfills. In this investigation, carbonation had the potential to lower the carbonate alkalinity from 7.4 to below $0.05 \mathrm{eq} \cdot(\mathrm{kg} \cdot \mathrm{FS})^{-1}$ (detection limit). Assuming that fly ash is pretreated by carbonation, and thereby leads to a depletion of carbonate alkalinity, abundant calcite will take over to buffer proton activity. According to the PLS model at high factor levels, the maximum calcite content was $\sim 250 \mathrm{~g} \cdot(\mathrm{kg} \cdot \mathrm{FS})^{-1}$. When the supply of calcite is dissolved, fly ash then becomes vulnerable to proton attack and significant metal mobilization can be expected.

To estimate decalcification in an open system, a first approximation is given by Appelo and Postma (1999): 
Table 2. Precipitation and Its Chemical Composition at Rickleå near Umeå, Sweden

\begin{tabular}{lcc}
\hline Variable & Unit & Value \\
\hline Amount & $\mathrm{mm} \cdot \mathrm{yr}^{-1}$ & 633 \\
$\mathrm{pH}$ & - & 4.66 \\
$\mathrm{NO}_{3}-\mathrm{N}$ & $\mathrm{ppm}$ & 0.26 \\
$\mathrm{NH}_{4}-\mathrm{N}$ & $\mathrm{ppm}$ & 0.19 \\
$\mathrm{SO}_{4}-\mathrm{S}$ & $\mathrm{ppm}$ & 0.43 \\
$\mathrm{Ca}$ & $\mathrm{ppm}$ & 0.16 \\
$\mathrm{Cl}$ & $\mathrm{ppm}$ & 0.38 \\
$\mathrm{Mg}$ & $\mathrm{ppm}$ & 0.04 \\
$\mathrm{Na}$ & $\mathrm{ppm}$ & 0.24 \\
$\mathrm{~K}$ & $\mathrm{ppm}$ & 0.15 \\
\hline
\end{tabular}

Note: Data from Kindbom et al. (1998).

$$
m_{\mathrm{Ca}^{2}}=\sqrt[3]{\frac{10^{-5.8} \times P_{\mathrm{CO}_{2}}}{4}}
$$

where the molality of $\mathrm{Ca}^{2+}\left(m_{\mathrm{Ca}^{2+}}\right)$ in the leachate is a function of the $\mathrm{CO}_{2}$ partial pressure $\left(\mathrm{P}_{\mathrm{CO}_{2}}\right)$ [for assumptions see Appelo and Postma (1999)]. This approach was refined by applying PHREEQC-2 to calculate decalcification at a fly ash landfill close to the MSW incinerator in Umeå. The model takes into account (1) the chemical composition of the rainwater in Umea (Table 2), (2) the redox equilibrium of the rainwater with atmospheric $\mathrm{O}_{2}$, (3) that $33 \%$ of evapotranspiration leads to an increase in the concentration of rainwater components, and (4) an in situ temperature of $5^{\circ} \mathrm{C}$ (Maurice and Lagerkvist 1997). When the $\mathrm{CO}_{2}$ partial pressure in the modeled landfill leachate was increased from $p \mathrm{CO}_{2}=3.5$ (atmosphere) to $p \mathrm{CO}_{2}=0.3$ (50\% by volume) (Fig. 6), $\mathrm{Ca}^{2+}$ increased from 30 to $369 \mathrm{ppm}$ while $\mathrm{pH}$ decreased from 8.28 to 6.22 . With an annual precipitation of $633 \mathrm{~mm}$, an in situ dry fly ash density of $1.5 \mathrm{t} \cdot \mathrm{m}^{-3}$, and a calcite content of $250 \mathrm{~g} \cdot(\mathrm{kg} \cdot \mathrm{FS})^{-1}$, decalcification of fly ash yields $0.13 \mathrm{~mm} \cdot \mathrm{yr}^{-1}$ when $\mathrm{CO}_{2}$ is at atmospheric conditions and $1.56 \mathrm{~mm} \cdot \mathrm{yr}^{-1}$ when $\mathrm{CO}_{2}$ is $50 \%$ by volume. The first value is the minimum expected decalcification rate. The second value gives an estimate once fly ash is codisposed with putrescible refuse, hence generating an excess of landfill gas through anaerobic respiration. This kind of codisposal should be considered carefully or refrained from. If the formation of $\mathrm{CO}_{2}$ in situ exceeds the amount needed to neutralize

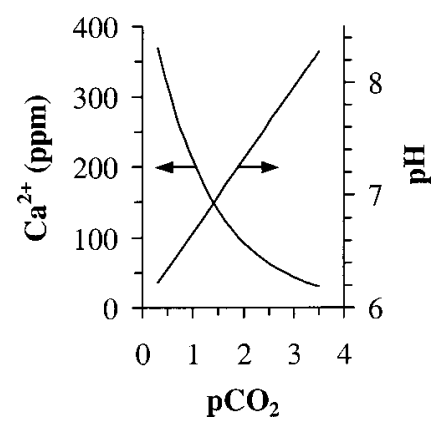

Fig. 6. $\mathrm{Ca}^{2+}$ concentration and $\mathrm{pH}$ in landfill leachate from carbonated fly ash as function of $p \mathrm{CO}_{2}$. The PHREEQC-2 calculations take account to (1) chemical composition of precipitation (Table 2), (2) redox equilibrium of rainwater with atmospheric $\mathrm{O}_{2}$, (3) 33\% evapotranspiration with respective increase in component concentration, and (4) in situ temperature of $5^{\circ} \mathrm{C}$. the carbonate alkalinity of fly ash, a $\mathrm{CO}_{2}$ level of $50 \%$ by volume causes a tenfold increase of the decalcification rate of fly ash, and thereby promotes metal mobilization.

Other possible factors that influence decalcification need to be thoroughly assessed, including the location and design of fly ash landfills. For example, some soils such as cat-clays (Brady and Weil 1999) could generate groundwaters with an acidic $\mathrm{pH}$, creating a risk of penetrating and subsequently leaching the fly ash.

Considering the limitations concerning landfill practices, carbonation is a promising stabilization method for most metal pollutants in MSWI fly ash. It might be conveniently performed as a pretreatment method, i.e., before the deposition of the fly ash. As a source of $\mathrm{CO}_{2}$, landfill gas should be tested. Landfill gas is abstracted at many landfill sites, is a reasonable resource, and is characterized by a $\mathrm{CO}_{2}$ content of $\sim 50 \%$ by volume, while the rest is mainly energy-rich $\mathrm{CH}_{4}$. Before $\mathrm{CH}_{4}$ is used, it could be purified through absorption in fixed bed filters of wetted fly ash. About $40 \mathrm{~g}$ of $\mathrm{CO}_{2}$ are retained per kg fixed solids (Fig. 4) which might not reverse but might mitigate the greenhouse effect.

On the basis of this bench-scale investigation, the authors recommend verification and improvement (or falsification) at pilot scale. With the exception of $\mathrm{Cd}$, the prospects are good that the strictest EC standards for landfill leachate can be met. Regarding $\mathrm{Cd}$, secondary sequestration processes such as silicate formation need to be assessed. If unsuccessful, preventive rather than remedial measures might be necessary, e.g., encouraging the separate collection and handling of NiCd batteries.

\section{Conclusions}

Carbonation of fly ash from municipal solid waste incineration was investigated at a laboratory scale. It had a remedial effect and is recommended for assessment at the pilot scale as a robust and reliable pretreatment technique to meet landfill standards.

The availability of critical elements such as $\mathrm{Pb}$ and $\mathrm{Zn}$ was reduced by two orders of magnitude. The partial pressure of $\mathrm{CO}_{2}$ had the largest influence toward reduced mobility followed by time, water addition, and temperature.

Chromium was demobilized mainly due to the addition of water while being remobilized with time probably because of oxidizing conditions caused by atmospheric oxygen during treatment. The latter calls for reducing environments during both treatment and landfilling.

Future investigations should pay extra attention to $\mathrm{Cd}$ because of its increased mobility during the treatment. To compensate for this effect, other sequestering processes such as silicate formation could be useful.

Extreme fly ash alkalinity was successfully remedied through carbonation.

During landfilling, long-term fly ash stability relies on the abundance of calcite. For a typical landfill in Sweden, decalcification of carbonated fly ash was estimated at $0.13 \mathrm{~mm} \cdot \mathrm{yr}^{-1}$ if controlled by atmospheric $\mathrm{CO}_{2}$. Higher partial pressure of $\mathrm{CO}_{2}$, as is probably caused by codisposal with putrescible refuse, increases the decalcification rate.

When determining the organic content of MSWI fly ash, the loss on ignition is erroneous by up to one order of magnitude because of the impact of both mechanically and chemically bound waters.

\section{Acknowledgements}

Thanks are due to Henrik Bristav (Umeå Energi AB), who ably provided us with the expertise of an incineration operator. The 
financial support of Ångpanneföreningens Forskningsstiftelse, UMEVA, Umeå Energi AB, Ragn-Sells AB, Birka Energi AB, RVF, and the Board of the Technical Faculty at Lulea University of Technology is greatly acknowledged.

Appelo, C. A. J., and Postma, D. (1999). Geochemistry, groundwater and pollution, Balkema, Rotterdam, The Netherlands.

Box, G. E. P., Hunter, W. G., and Hunter, J. S. (1978). Statistics for experimenters, Wiley, New York.

Brady, N. C., and Weil, R. R. (1999). The nature and properties of soils, Prentice-Hall, London.

CEN. (2000). "Characterization of sludges-Determination of the loss on ignition of dry mass." European Committee for Standardization No. EN 12879, Brussels, Belgium.

Chandler, A. J., Eighmy, T. T., Hartlén, J., Hjelmar, O., Kosson, D. S., Sawell, S. E., van der Sloot, H. A., and Vehlow, J. (1997). Municipal solid waste incinerator residues, Elsevier, Amsterdam, The Netherlands.

Cooley, W. W., and Lohnes, P. R. (1971). Multivariate data analysis, Wiley, New York.

Cremer, S., and Obermann, P. (1992). "Mobilisierung von Schwermetallenin Porenwässern von belasteten Böden und Deponien: Entwicklung eines aussagekräftigen Elutionsverfahrens." Materialien zur Ermittlung und Sanierung von Altlasten, Band 6, Landesamt für Wasser und Abfall NRW, Düsseldorf (in German).

Ecke, H., Menad, N., and Lagerkvist, A. (2002). “Treatment-oriented characterization of dry scrubber residue from municipal solid waste incineration (MSWI)." J. Mater. Cycles Waste Management, 4(2), $117-126$.

Ecke, H., Sakanakura, H., Matsuto, T., Tanaka, N., and Lagerkvist, A. (2000). "State-of-the-art treatment processes for municipal solid waste incineration residues in Japan." Waste Manage. Res., 18(1), 41-51.

Eighmy, T. T., Crannell, B. S., Butler, L. G., Cartledge, F. K., Emery, E. F., Oblas, D., Krzanowski, J. E., Eusden, J. D. J., Shaw, E. L., and Francis, C. A. (1997). "Heavy metal stabilization in municipal solid waste combustion dry scrubber residue using soluble phosphate." Environ. Sci. Technol., 31(11), 3330-3338.

European Union (EU). (1991). Council Directive 91/689/EEC of 12 December 1991 on Hazardous Waste, The Council of the European Union, Brussels, Belgium.

European Union (EU). (1999). Council Directive 1999/31/EC of 26 April 1999 on the Landfill of Waste, The Council of the European Union, Brussels, Belgium.

Gutjahr, A., Dabringhaus, H., and Lacmann, R. (1996). "Studies of the growth and dissolution kinetics of the $\mathrm{CaCO}_{3}$ polymorphs calcite and aragonite. II: The influence of divalent cation additives on the growth and dissolution rates." J. Cryst. Growth, 158(3), 310-315.

Hjelmar, O., Johannessen, L. M., Knox, K., Ehrig, H.-J., Flyvbjerg, J., Winther, P., and Christensen, T. H. (1994). "Management and composition of leachate from landfills." Contract No. B4-3040/013665/ 92, Commission of the European Communities, Brussels, Belgium.

Kindbom, K., Sjöberg, K., Munthe, J., Peterson, K., Persson, C., Roos, E., and Bergström, R. (1998) "National miljöövervakning av luft-och nederbördskemi 1996.” Rep. No. B1289 IVL, Swedish Environmental Research Institute, Gothenburg, Sweden.

Maurice, C., and Lagerkvist, A. (1997). "Seasonal variation of landfill gas emissions." 6th Int. Landfill Symposium, Environmental Sanitary Engineering Center (CISA) Cagliari, Italy, 87-93.

Ministry of Health and Welfare (MHW). (1991). Nihon no haikibutsu shori (Waste management in Japan), Water Supply and Environmental Sanitation Department, Environmental Health Bureau, Tokyo (in Japanese).

Morse, J. W., and Bender, M. L. (1990). "Partition coefficients in calcite: Examination of factors influencing the validity of experimental results and their application to natural systems." Chem. Geol., 82, 265-277.

Parkhurst, D. L., and Appelo, C. A. J. (1999). User's guide to PHREEQC (version 2) - A computer program for speciation, batch-reaction, onedimensional transport, and inverse geomchemical calculation, U.S. Geological Survey, Denver.

Reardon, E. J., and Della Valle, S. (1997). "Anion sequestering by the formation of anionic clays: lime treatment of fly ash slurries." Environ. Sci. Technol., 31(4), 1218-1223.

Reddy, K. J., Drever, J. I., and Hasfurther, V. R. (1991). "Effects of $\mathrm{CO}_{2}$ pressure process on the solubilities of major and trace-elements in oil-shale solid-wastes." Environ. Sci. Technol., 25(8), 1466-1469.

Reddy, K. J., Gloss, S. P., and Wang, L. (1994). "Reaction of $\mathrm{CO}_{2}$ with alkaline solid wastes to reduce contaminant mobility." Water Res., 28(6), 1377-1382.

Rimstidt, J. D., Balog, A., and Webb, J. (1998). "Distribution of trace elements between carbonate minerals and aqueous solutions." Geochim. Cosmochim. Acta, 62(16), 1851-1863.

Schwartz, M. O., and Ploethner, D. (2000). "Removal of heavy metals from mine water by carbonate precipitation in the GrootfonteinOmatako canal, Namibia." Environ. Geol., 39(10), 1117-1126.

Stumm, W. (1992). Chemistry of the solid-water interface, Wiley, New York.

Tawfic, T. A., Reddy, K. J., Gloss, S. P., and Drever, J. I. (1995). "Reaction of $\mathrm{CO}_{2}$ with clean coal technology ash to reduce trace element mobility." Water, Air, Soil Pollut., 84(3-4), 385-398.

Wold, S. (1989). "Multivariate data analysis: converting chemical data tables to plots." Intell. Instrum. Comput., 197-216.

Wold, S., Esbensen, K., and Geladi, P. (1987). "Principal component analysis." Chemom. Intell. Lab. Syst., 2, 37-52. 